\title{
ROLE AND FUNCTION OF ETHYLENE RESPONSE FACTOR IN DIFFERENT PLANTS UNDER MULTIPLE BIOTIC AND ABIOTIC STRESSES
}

\author{
Rabia Akram ${ }^{1}$, Farah Deeba ${ }^{1}$, Maryam zain ${ }^{1,}$ Nadia Iqbal ${ }^{1 *}$ \\ ${ }^{1}$ Department of Biochemistry and Biotechnology, The Women University, Multan, Pakistan \\ *Corresponding Author: \\ Dr. Nadia Iqbal \\ Department of Biochemistry and Biotechnology, The Women University, Multan, Pakistan \\ Naaaadia7@gmail.com
}

\begin{abstract}
Abiotic and biotic stresses are the causes of drastic changes in plants growth and development. These stresses effect crop production and quality, thus result is in economic lose and food insecurity. Many factors play vital role in regulating growth of plants along with developmental pathways during biotic and abiotic stresses. Transcription factors are proteins that control physiological, developmental and stress responses in plants. Ethylene response factors belong to the biggest family of transcription factors, known to participate in various stress tolerance like drought, heat, salt and cold. They are significant regulators of plant gene expression. The objective of this review is to present how ethylene response factor family proteins became the focus of stress tolerance as well as the development and growth of plants.
\end{abstract}

\section{INTRODUCTION}

Plants are susceptible to several types of environmental stresses throughout their life cycle. These adverse environmental conditions, specifically high salt concentration, temperature, soil moisture affect the growth, development, yield and geological distribution of cultivated crops across the world and decrease possible crop productivity approximately to $70 \%(1)$.

Biotic stresses for example weeds, diseases and insects occur at variable extent which may not be relevant in a particular developmental stage but decrease plant productivity (2). One of the main objective of cop breeding program is development of stress tolerant crop (3). Several 
widespread abiotic stresses reported to take place around the world are salinity (4), drought (5), water logging, extreme temperatures (6), also nutrient deficiency (7).

A variety of defense mechanism like maintenance of membrane integrity, generation of antioxidants, hormone regulation, stimulation of stress proteins and carbon fixation rate have been found to work in plant. Various mechanisms in plant are governed involving particular genes for these stresses $(8)$ and help plants to protect against a series of outside stresses during morphological adaptation (9). A large number of genes with diverse functions are induced or repressed when a plant is undergo to abiotic stresses. These genes encode for proteins which could be divided into two groups. One of them is primary group comprises functional proteins that is key enzymes for osmolytes biosynthesis like proline and sugar alcohols, molecular chaperones, and membrane transporters which are directly related to defense of plants from abiotic stress. The other group contains proteins that are regulatory in nature and control signal transduction and stress receptive gene expression and consists of a variety of transcription factors and protein kinases $(10)$.

Transcription factors (TFs) that are regulatory proteins have a central part in initiating defense gene expression (11). They interact through cis-acting components present in promoter region of various stress regulated genes and consequently start cascades or entire system of genes that perform together increased tolerance to various stresses at a time. Stress responsive transcription factors are strong tools for genetic engineering because their overexpression can result in either upregulation or downregulation of entire collection of genes under their control. A large number of transcription factors participate in plant stress tolerance and regulate plant responses to diverse stresses. In Arabidopsis more than 1500 genes have reported to encode a various transcription factors (12). Some of the transcription factors related to plant stress response are categorized into numerous large families for example AP2/ERF, NAC, bZIP, zincfinger,MYB, MYC and WRKY (13). Ethylene responsive factor is the member of large gene family the APETALA2/Ethylene-Responsive Factor superfamily. This superfamily also include AP2as well as RAV family(12). This superfamily has characteristic AP2/ERF domain, which contains near about sixty to seventy amino acids. The families of AP2/ERF superfamily defined like, proteins of AP2 family have AP2/ERF domains which are two repeated domains, and proteins of ERF family consist of one domain that is AP2/ERF, whereas proteins of RAV family have a B3 domain. The ethylene response factor family is further divided into two distinctive subfamilies, one is CBF/DREB subfamily, second is ERF subfamily (14). The ERF region initially identified as conserved element in four proteins characterized in Nicotiana 
tabacum. These proteins are distinctive ethylene responsive element binding proteins, named ERF 1, 2, 3, 4 also found to interact with consensus promoter sequence GCC box which play role in ethylene responsive transcription of genes (15). The ERF subfamily proteins were classified into six sets, B-1 to B-6. Nakano et al., (16) studied the expression of various genes of ERF subfamily in various plants and their biological roles.

The ethylene responsive factors also governed by feedback mechanism and may be ethylene dependent or ethylene independent. Apart from regulation mechanism, ERFs expressions are regulated post-transcriptionally via micro RNAs, while expressions of miRNA are also regulated through ERFs. Ethylene responsive factors have found to involve as activator or various genes while it may act as repressor of various genes during of plants defense response averse to biotic stress condition (17). Ethylene responsive factors also defense role in fungal and bacterial diseases responses as well as during viral infection in plants (18). SERF1 overexpression enhanced tolerance of salinity through ROS stimulated MAPK indicating flow (19). TaERF1 in wheat was appeared in the direction of improve easiness to abiotic, also biotic stress conditions (20). AP2/EREBP family which are plant-specific TFs exposed by Arabidopsis mutational analysis, that were liable for enhance wax substance, decline stomatal density, changed cuticle premises in addition to the connected important raise in tolerance of drought Arabidopsis (21).

Ethylene response factors $(E R F)$ are associated in stress tolerance in a number of species of plants (22), it was revealed that GhERF2, GhERF3 and GhERF6 can proceed as significant frequent components of various signaling pathways receptive to abiotic and biotic stresses. To advance identify with their activity, the development of transgenic plants overexpressing these genes is ongoing (23).

\section{Discovery of Ethylene response Factor}

ERFs previously named ethylene response binding proteins denoted by ERE binding proteins. The ethylene responsive element proteins earliest extracted from plant Nicotiana tabacum (15). ERFs consist of a domain, AP2 DNA-binding region, as of a plant-definite fabulous family of 122 TFs in Arabidopsis. In genome of tomato, near 85 gene of ethylene responsive factors family protein stay uncharacterized (24). It is described that in various plants ERF domains product be present within several regulatory genes $(25,26)$ but is not present in fungi, yeast or mammalian (27). In the most recent decade, to a large extent, consideration have been accentuated on AP2/ERF large family. The hypothesis elucidates as the lateral gene movement 
of $\mathrm{HNH}-\mathrm{AP} 2$ endonuclease originated from bacteria or virus into the host plant might bring about regenerate the AP2/ERF great family (28).

\section{Functional Diversity in Plants}

Up to now, Ethylene responsive TFs have been recognized as well as distinguished from numerous species of plants for example Arabidopsis (16), poplar (29), cotton (30), soybean (31), barley (32), maize (33), cucumber (34), apple, wheat (35), rice (36), sorghum (37), Medicago truncatula (38), also potato (39). Overall 147 genes in Arabidopsis, encoding AP2/ERF TFs, transcription factors named ERF encoded by 122 of these 147. ERF TFs of Arabidopsis may be divided into 12 groups different from each other, found on phylogenetic analysis, these groups named as I to $\mathrm{X}, \mathrm{VI}-\mathrm{L}, \mathrm{Xb}-\mathrm{L}$ (16).Functional diversity of ethylene response factor in different plants is given in table 1.

\section{Structure}

The ERF TFs take part in plants development procedures, in response to environmental stresses and hormone signaling (39). The ethylene response factor family has been comprehensively studied in recent times. In AP2/ERF domain b-sheet, 2 conserved amino acid residues distinguished ERF transcription factors, residues are 14th Ala as well as $19^{\text {th }}$ Asp (14).ERF TFs allocate a conserved 58-59 amino acid domain (the ethylene response factor domain) and encompass sturdy capability to bind an extensive sort of CREs within promoter of mark genes. From the cis-regulatory elements, DRE/CRT and GCC-box are the two chief DNA-binding elements (40). Most stimulatingly, numerous studies expose ERF proteins interconnect by DRE/CRT motif, a cis-acting element which acts in response to osmotic stress or cold (41), they build up defense by interrelating among stress-regulated genes (42).

The $\alpha$-helix as well as $\beta$-sheet of ERF region identify the GCC box (called core cis-acting element AGCCGCC) of objective DNA on the ER promoter region (43). Pathogenesis-related (PR) genesare expressed by these GCC box elements (44). Additionally, the minority conservative elements of other than AP2 region grant transcriptional repression or activation in favor of particular gene, for example ERF connected amphiphilic oppression element that is EAR: DLNxxP (45), LWSY element(30)in addition to B3 oppression domain motif that is BRD:RLFGV (46). ERF protein either has homology resemblance with identified DNA joining proteins nor has fundamental zinc finger or leucine zipper elements, which propose ERF is a 
set of novel DNA binding proteins (43).Figure 1 gives classification and highlights functional association among AP2/ERFs in a variety of abiotic stress responses plants.

\section{Role of ethylene response factor}

Ethylene responsive factors take part essential regulatory tasks in various developmental processes and stress responses in plants. Genes of ERF family in an extensive array of plant types, were categorized into 8groups and 14 subgroups on the base of gene structures, conserved motifs, phylogenetic relationships, and biological functions. ERF genes, particularly in groups II as well as VII, may be utilized like contenders to develop crop resistance, for the reason that overexpression of ERF genes increases various disease resistance along with tolerance to drought, salt, freezing also in transgenic plant. The inclusive testing of phylogenetic correlations, conserved pattern, moreover physiological functions is beneficial in lighlighting the biological roles of genes of ERF family in signal transduction, gene regulation along with defense response below stress environments (11).

ERF TFs have been revealed to be concerned in the regulation of expression of lipids, cell wall constituents, pathogenesis related genes, biosynthesis genes, basic type defense related genes, chitinase, osmotin, more over b-1,3-glucanase encoding genes (28). Few of them are exposed to be concerned with in the control of plant reactions to biotic, also abiotic pressures by either activating or repressing abscisic acid responsive genes (47). Such as AtERF4 over-expression plant was a smaller amount of responsive to $\mathrm{ABA}$ suppressed root enlargement that entails negative control of ABA also ethylene reactions (48). The expression of ABA-responsive genes are repressed by AtERF7 that binds to the GCC box (49). ERF111 or ABR1 takes part as a negative controller of $\mathrm{ABA}$ reactions throughout seed germination, $\mathrm{ABA}$ and stress regulated gene expression (50) wherever as in Arabidopsis ABA hypersensitivity is conferred by transgenic plant, overexpressing AtERF13 (51). AtERF15 exposed on the way to proceed as activist controller of ABA reactions (52). In contrast, ABA may also bring about the few ERF genes expression such as the expression of tomato ERF gene JERF1/3, cotton ERF gene GbERF in addition to tobacco ERF gene NtCEF1 has been revealed to be evoked by ABA (53).Sub group IX in IXERF subfamily accommodates 4 tiny ERFs through amino acids, varied as of 131-139. These tiny ethylene response factors named ERF95, ERF96, ERF97, ERF98. Additionally toward AP2/ERF area, these ethylene response factor have unfamiliar role pattern termed CMIX-1 (16). In the group of these, ERF95 in addition called ethylene and salt inducible1 (ESE1), furthermore ERF98 have been exposed to concerned with the control of 
salt tolerance (54). In the past ERF97 termed AtERF14, has been revealed to control plants protection (55). In recent times ERF96 also has been revealed to regulate plant defense response (56).

\section{Role of ERF during Stress}

ERFs are concerned during the parameter of plant growth, expansion, metabolism as well as plant reactions to ecological stimulus like abiotic and biotic stresses (57). The ERF transcription factors are participated in the ethylene signaling pathway as well as directing in the direction of the expression of a variety of protection-associated genes, for example pathogenesis-related genes (40), abiotic stress receptive genes (58). The existence of a GCCbox or a dehydration responsive element/C-repeat element (DRE/CRT, CCGAC) situated in the promoter sequences ofdefense-related genes are involved in characterization of these genes (14). Figure 2 shows stress related genes expression, their role under stresses

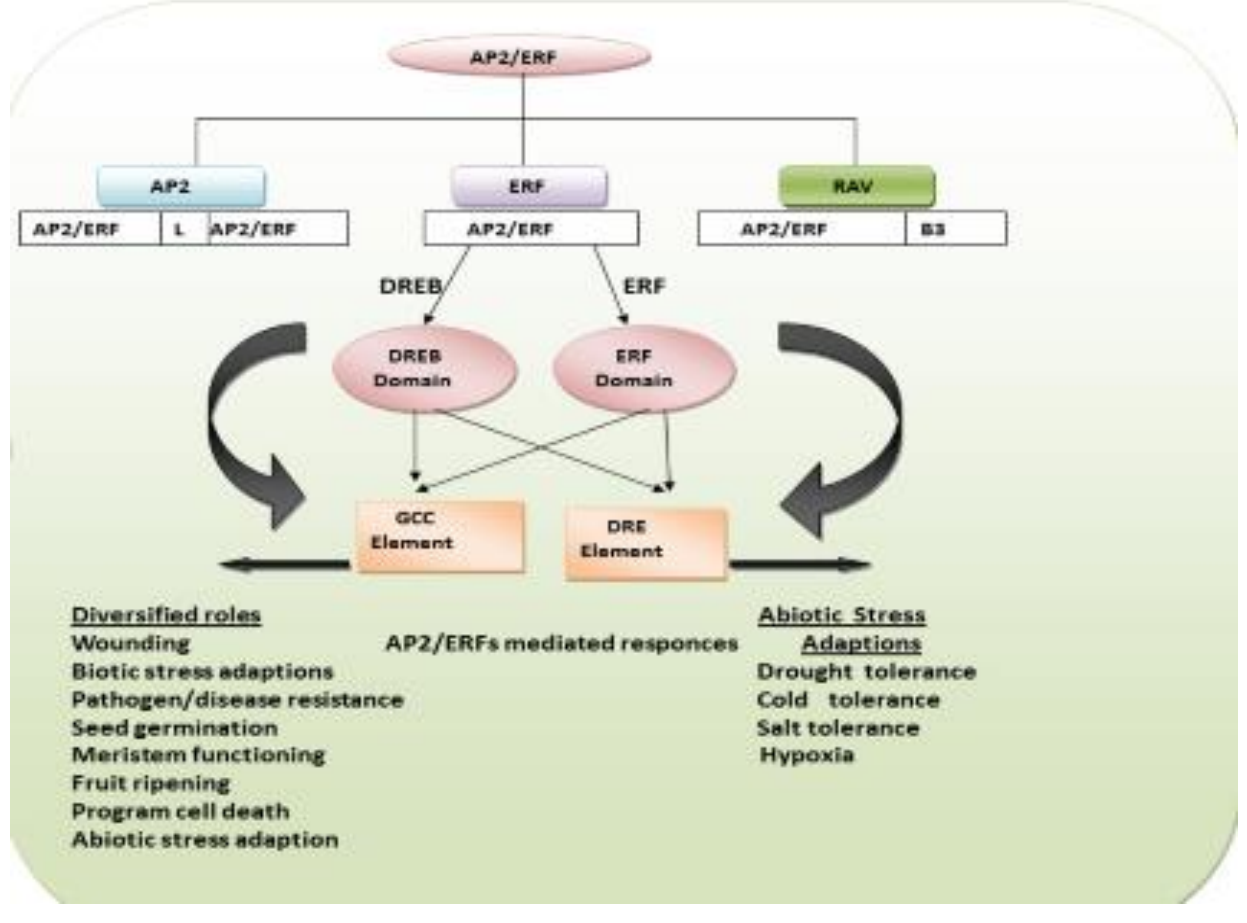

Figure 1: AP2/ERF transcription factors in plants, their classification and their functions has also been reported.

Table 1: Examples of ERF family proteins involved in regulation of multiple abiotic stress responses in different plants. 


\begin{tabular}{|c|c|c|c|}
\hline ERF Gene & $\begin{array}{l}\text { Identified in plant } \\
\text { species }\end{array}$ & Function & References \\
\hline TaERF3 & Triticum aes tivron (Wheat) & Drought and salinity tolerance & $(79)$ \\
\hline TaERFI & Triticum aes tivron (Wheat) & Drought, salt, and low temperature toler ance & $(20)$ \\
\hline AtERFO19 & Arabidopsis (Mouseear cress) & $\begin{array}{l}\text { Drought tolerance, smaller stomata aperture, and lower } \\
\text { transpiration rate }\end{array}$ & $(80)$ \\
\hline DREBIA & $\begin{array}{l}\text { Arabidopsis } \\
\text { (Mouseear cress) }\end{array}$ & Delayed water stress symptoms & $(8 I)$ \\
\hline SOdERF3 & $\begin{array}{l}\text { Saccharum officinarum } \\
\text { (Sugercane) }\end{array}$ & Drought and osmotic tolerance & $(82)$ \\
\hline OsERF $4 a$ & Oryza sativa (Rice) & Enhanced drought tolerance & $(83)$ \\
\hline$A t E R F 7$ & $\begin{array}{l}\text { Arabidopsis } \\
\text { (Mouseear cress) }\end{array}$ & $\begin{array}{l}\text { AtERF7 binds to the } G C C \text { box and acts as a transcriptional } \\
\text { repressor in } A B A \text { and drought stress responses. }\end{array}$ & (84) \\
\hline OsERF3 & $\begin{array}{l}\text { Oryza sativa } \\
\text { (Rice) }\end{array}$ & $\begin{array}{l}\text { EAR motif in OsERF3 is required to transcriptionally regulate } \\
\text { ethylene biosynthesis and drought toler ance. }\end{array}$ & $(38)$ \\
\hline OsERF4a & Oryza sativa (Rice) & $\begin{array}{l}\text { OsERF } 4 \text { a improves drought tolerance through the repression of a } \\
\text { downstream suppressor of stress response gene, Sir } 2\end{array}$ & $(83)$ \\
\hline GmERF6 & Oryza sativa (Rice) & $\begin{array}{l}\text { GmERF6 functions as an EAR repressor to downregulate } \\
\text { expression of } A t K i n l, A t P R 3 \text { and } A t R D 22 \text { in transgenic } A \text {. } \\
\text { thalicona }\end{array}$ & $(85)$ \\
\hline SIERF36 & $\begin{array}{l}\text { Solanum bcopersicum } \\
\text { (Tomato) }\end{array}$ & $\begin{array}{l}\text { The EAR motif in S1ERF36 controls early flowering and } \\
\text { senescence and is responsible for reduction of stomatal density } \\
\text { and photosynthesis }\end{array}$ & (86) \\
\hline OsERF71 & Oryza sativa (Rice) & Positive regulator in Drought salinity & $(87)$ \\
\hline GhERFTOD & $\begin{array}{l}\text { Gossypiton herbacelom (Levant } \\
\text { cotton) }\end{array}$ & Positive regulator in cold stress & $(88)$ \\
\hline GhDREB56A & $\begin{array}{l}\text { Gossypizon herbaceron (Levant } \\
\text { cotton) }\end{array}$ & Positive regulator in heat sress & $(88)$ \\
\hline GhDREB $7 A$ & $\begin{array}{l}\text { Gossypizon herbacezon (Levant } \\
\text { cotton) }\end{array}$ & Drought, heat, and cold & $(88)$ \\
\hline$A t E R F O 19$ & Arabidopsis (Mouseear cress) & Drought & $(89)$ \\
\hline$B d E R F 14$ & $\begin{array}{l}\text { Brachypodizon distachyon } \\
\text { (Purple false brome) }\end{array}$ & Drought, salt, cold & $(90)$ \\
\hline$B d E R F 118$ & $\begin{array}{l}\text { Brachypodizon distachyon } \\
\text { (Purple false brome) }\end{array}$ & Negative regulator in cold stress & $(90)$ \\
\hline ERFI09 & Nicotiana tabacion (Tobacco) & Positive regulator in Salt & $(9 I)$ \\
\hline MeERFI7 & Manihot esculenta (Cassava) & Positive regulator in drought & $(92)$ \\
\hline $\mathrm{ZmCBF3}$ & Zea mays (Corn) & Negative regulator in Cold & $(93)$ \\
\hline StERFI & Solanum tuberosum (Potato) & $\begin{array}{l}\text { Positive regulator of Salt, drought, and hormonal like methyl } \\
\text { jasmonate }\end{array}$ & $(94)$ \\
\hline Sl-ERF.B.3 & bcopersicum & Positive or Negative regulator of Heat, cold and flood, drought & (95) \\
\hline LeERF3b & $\begin{array}{l}\text { Solamum bcopersicum } \\
\text { (Tomato) }\end{array}$ & Positive regulator of Drought, desiccation, and low temperature & (96) \\
\hline
\end{tabular}




\title{
Role of ERF during Stress
}

ERFs are concerned during the parameter of plant growth, expansion, metabolism as well as plant reactions to ecological stimulus like abiotic and biotic stresses (57). The ERF transcription factors are participated in the ethylene signaling pathway as well as directing in the direction of the expression of a variety of protection-associated genes, for example pathogenesis-related genes (40), abiotic stress receptive genes (58). The existence of a GCCbox or a dehydration responsive element/C-repeat element (DRE/CRT, CCGAC) situated in the promoter sequences of defense-related genes are involved in characterization of these genes (14). Figure 2 shows stress related genes expression, their role under stresses.

\begin{abstract}
Abiotic Stress
Environmental stresses that are nutrient deficiency, drought, salinity, extreme temperatures and chemical toxicity, leads to a chain of physiological, morphological, molecular, and biochemical changes which negatively have an effect on plant development, yield and survival all-inclusive (59); (60), in response to those stresses plants develop mechanisms. Plant feedbacks are multifarious, including extensive metabolic and transcriptional events (61). The molecular and physiological studies of environmental stresses have proposed a familiar network of several signaling tracks that mediate salt, extreme temperatures and drought stress responses in plants (62). In abiotic stress responses the DREBs proteins are most extremely considered ethylene response factor. Elements of the subfamily $D R E B 1 / C B F s$ are quickly induced in retort to chilly stress and get better tolerance to freezing when expressed ectopically, (63). Whereas, RNAi lines of Arabidopsis for $C B F 1$ or $C B F 3$ have decreased cold tolerance (64). For freezing tolerance $C B F 2$ associated by quantitative trait locus (65), point out that $D R E B 1 / C B F$ genes are cold activated and in Arabidopsis are liable to be main monitor of reaction to wintry stress. Furthermore in Arabidopsis CBF2 abnormal gene communication has been revealed to retard leaf senescence, indicating that $C B F s$ promotes extremely cold temperature tolerance (66).
\end{abstract}




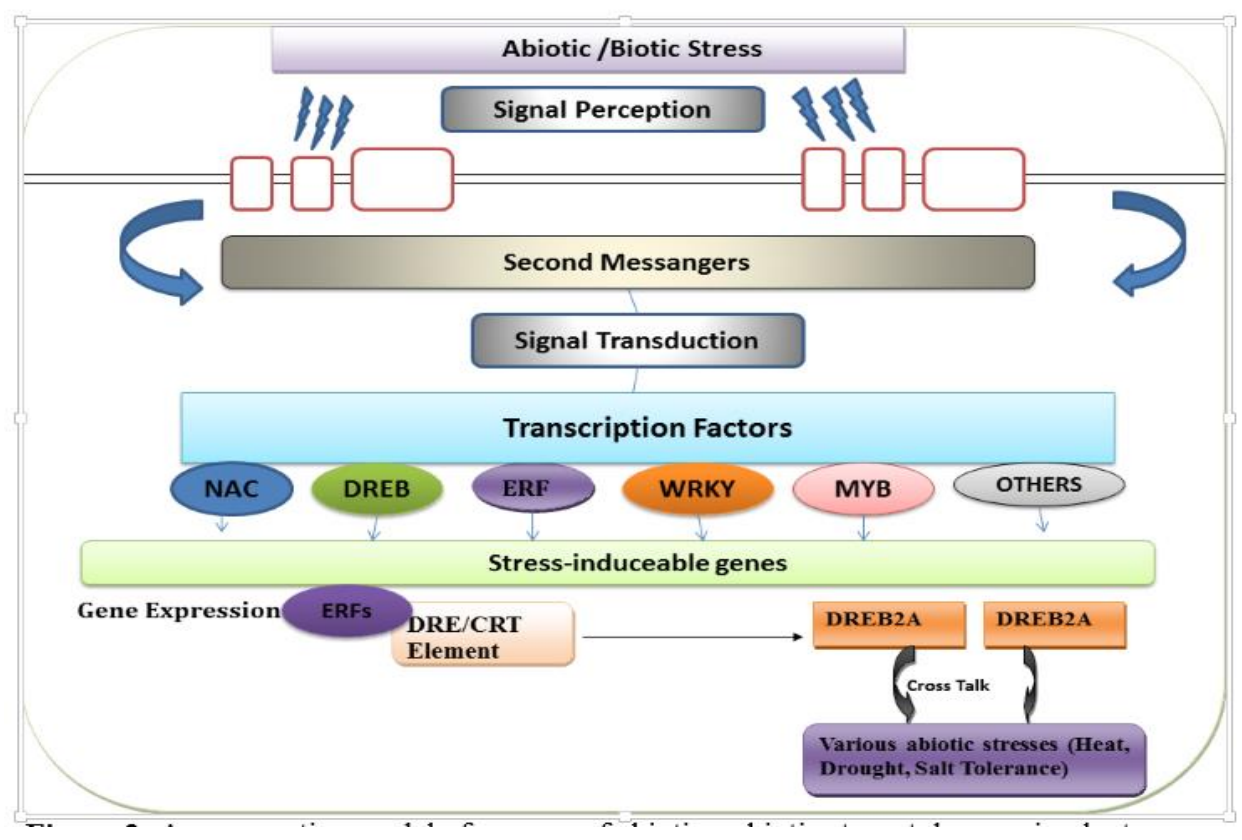

Figure 2: A model of process of abiotic or biotic stress tolerance in plants.

The subgroup of DREB2 contains eight elements in Arabidopsis and more homologs in the genetic material of numerous angiosperm families. Along with the components of the DREB2 sub division, Arabidopsis DREB2A as well as DREB2B were induced in loss of water, heat and elevated saltiness in an ABA independent way (67). The abnormal gene expression of a constitutively dynamic structure of DREB2A demonstrates developed forbearance to famine, heat and elevated salt stresses $(67,68)$ whereas DREB2A are further susceptible to temperature Shock (67). From rice or Arabidopsis several ERF-VII genes are exposed to be participated with in response to hypoxia as well as submergence (69).In Arabidopsis RAP2.12 are constitutive ERF-VII factors, they are recommended to proceed as prime triggers for the molecular feedback to insufficiency of oxygen (70); (71), that is then comforted at the oxygen deprivation activated ethylene response factors HRE1 also HRE2 (72). In submerged deep water rice, SK1 and SK2 motivate internodes elongation to effect clearance of the water level (73), whereas Sub1A promotes a quiescent strategy that allows carbohydrate saving and improves tolerance after flash-flood (74). A number of $E R F$ genes from various plants have been exposed to confer various stress tolerance when expressed ectopically (75). This 'unspecific' effect may be explained by the activation of tolerance pathways which reduce a common stress including oxidative bursts generated as results of the primary stresses. Otherwise constitutive ERF expression could set the plant in a common alert state that fasten or expand the response when a specific stress is applied (28). 


\section{Biotic Stress}

ERFs are entailed in biotic stress responses, ethylene response factor proteins initially extracted the same as transcription factors (TFs) which connect to promoter regions of stress-responsive genes. ERF genes assessed to date, are provoked through biotic stresses, consist of wounding, pathogen induced stresses, such as transcription of basic type pathogenesis-related (PR) genes, defense-related genes, chitinase, osmotin, and b-1,3-glucanase activated by numerous ERFs. On the other hand, the group of target genes regulated by each ERF has not been fully discovered. ERF1 as well as its homologs be associated to ERF-IX group, are possibly the ERF transcription factors whose participation in pathogen reaction in Arabidopsis has been most widely distinguished (76), as well a number of proteins of ERF regulate ethylene biosynthesis (77). Tobacco OPBP1 when expressed ectopically in transgenic rice increases resistance to pathogens (78).

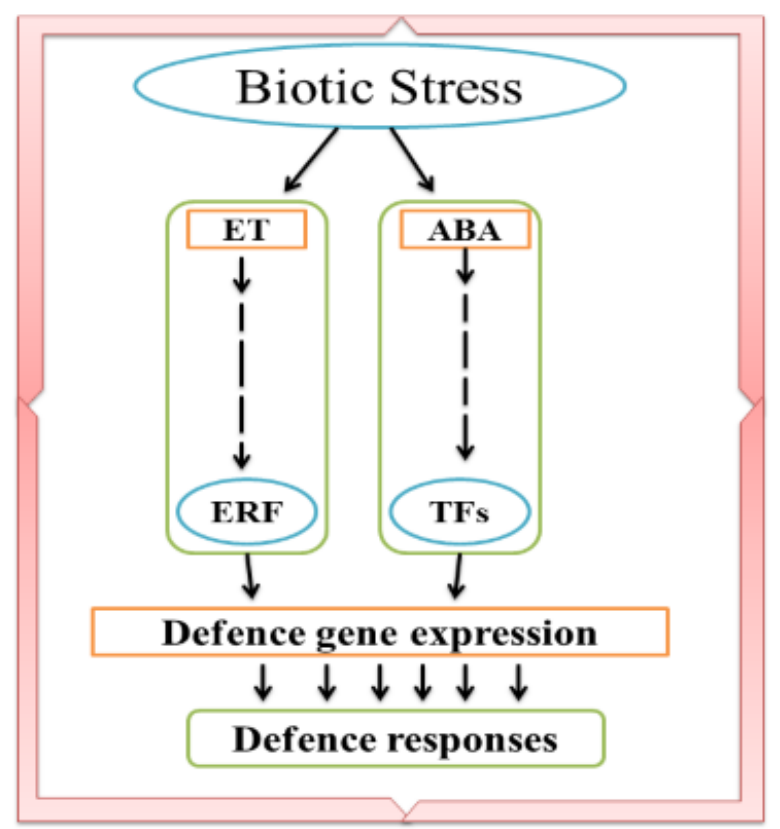

Figure 3: Hormonal signalling and expression of genes in biotic stresses.

\section{Conclusion}

The existing information about various roles ofAP2/ERFs recommends that the members of this large super family can be utilized for improving stress tolerance for better crop yields. The members of this family can be employed in improving nutritional quality of grown varieties. 
Up to now extensive advancement has been done to know the functions ofAP2/ ERFs in response to various stresses. To develop multiple stress tolerant crops the members of this superfamily have been used. The plants genome sequencing projects have facilitated for recognition of ethylene response factors in different plants. It is stated that the proteins of ERF family has ability to confer resistance against numerous stresses in crop plant.

\section{References}

1. Agarwal, P. K.; Agarwal, P.; Reddy, M.; Sopory, S. K., Role of DREB transcription factors in abiotic and biotic stress tolerance in plants. Plant cell reports. 2006, 25 (12), 1263-1274.

2. Yang, C.; Guo, W.; Li, G.; Gao, F.; Lin, S.; Zhang, T., QTLs mapping for Verticillium wilt resistance at seedling and maturity stages in Gossypium barbadense L. Plant Science. 2008, 174 (3), 290-298.

3. Fritsche-Neto, R.; Borém, A. Plant breeding for biotic stress resistance; Springer: 2012.

4. Shrivastava, P.; Kumar, R., Soil salinity: a serious environmental issue and plant growth promoting bacteria as one of the tools for its alleviation. Saudi journal of biological sciences. 2015, 22 (2), 123-131.

5. Aroca, R.; Ruiz-Lozano, J. M., Regulation of root water uptake under drought stress conditions. In Plant responses to drought stress, Springer: 2012; pp 113-127.

6. Theocharis, A.; Clément, C.; Barka, E. A., Physiological and molecular changes in plants grown at low temperatures. Planta. 2012, 235 (6), 1091-1105.

7. Liang, C.; Tian, J.; Liao, H., Proteomics dissection of plant responses to mineral nutrient deficiency. Proteomic.s 2013, 13 (3-4), 624-636.

8. Khan, A.; Pan, X.; Najeeb, U.; Tan, D. K. Y.; Fahad, S.; Zahoor, R.; Luo, H., Coping with drought: stress and adaptive mechanisms, and management through cultural and molecular alternatives in cotton as vital constituents for plant stress resilience and fitness. Biological research. 2018, 51 (1), 47.

9. Boudsocq, M.; Laurière, C., Osmotic signaling in plants. Multiple pathways mediated by emerging kinase families. Plant physiology. 2005, 138 (3), 1185-1194.

10. Lata, C.; Prasad, M., Role of DREBs in regulation of abiotic stress responses in plants. Journal of experimental botany. 2011, 62 (14), 4731-4748.

11. Xu, Z.-S.; Chen, M.; Li, L.-C.; Ma, Y.-Z., Functions of the ERF transcription factor family in plants. Botany. 2008, 86 (9), 969-977. 
12. Riechmann, J. L.; Heard, J.; Martin, G.; Reuber, L.; Jiang, C.-Z.; Keddie, J.; Adam, L.; Pineda, O.; Ratcliffe, O.; Samaha, R., Arabidopsis transcription factors: genome-wide comparative analysis among eukaryotes. Science. 2000, 290 (5499), 2105-2110.

13. Umezawa, T.; Fujita, M.; Fujita, Y.; Yamaguchi-Shinozaki, K.; Shinozaki, K., Engineering drought tolerance in plants: discovering and tailoring genes to unlock the future. Current opinion in biotechnology. 2006, 17 (2), 113-122.

14. Sakuma, Y.; Liu, Q.; Dubouzet, J. G.; Abe, H.; Shinozaki, K.; Yamaguchi-Shinozaki, K., DNA-binding specificity of the ERF/AP2 domain of Arabidopsis DREBs, transcription factors involved in dehydration-and cold-inducible gene expression. Biochemical and biophysical research communications. 2002, 290 (3), 998-1009.

15. Ohme-Takagi, M.; Shinshi, H., Ethylene-inducible DNA binding proteins that interact with an ethylene-responsive element. The Plant Cell. 1995, 7 (2), 173-182.

16. Nakano, T.; Suzuki, K.; Fujimura, T.; Shinshi, H., Genome-wide analysis of the ERF gene family in Arabidopsis and rice. Plant physiology. 2006, 140 (2), 411-432.

17. Maruyama, Y.; Yamoto, N.; Suzuki, Y.; Chiba, Y.; Yamazaki, K.-i.; Sato, T.; Yamaguchi, J., The Arabidopsis transcriptional repressor ERF9 participates in resistance against necrotrophic fungi. Plant science. 2013, 213, 79-87.

18. Chen, T.; Lv, Y.; Zhao, T.; Li, N.; Yang, Y.; Yu, W.; He, X.; Liu, T.; Zhang, B., Comparative transcriptome profiling of a resistant vs. susceptible tomato (Solanum lycopersicum) cultivar in response to infection by tomato yellow leaf curl virus. PloS one. 2013, 8 (11).

19. Schmidt, R.; Mieulet, D.; Hubberten, H.-M.; Obata, T.; Hoefgen, R.; Fernie, A. R.; Fisahn, J.; San Segundo, B.; Guiderdoni, E.; Schippers, J. H., SALT-RESPONSIVE ERF1 regulates reactive oxygen species-dependent signaling during the initial response to salt stress in rice. The Plant Cell. 2013, 25 (6), 2115-2131.

20. Xu, Z.-S.; Xia, L.-Q.; Chen, M.; Cheng, X.-G.; Zhang, R.-Y.; Li, L.-C.; Zhao, Y.-X.; Lu, Y.; Ni, Z.-Y.; Liu, L., Isolation and molecular characterization of the Triticum aestivum L. ethylene-responsive factor 1 (TaERF1) that increases multiple stress tolerance. Plant molecular biology. 2007, 65 (6), 719-732.

21. Aharoni, A.; Dixit, S.; Jetter, R.; Thoenes, E.; van Arkel, G.; Pereira, A., The SHINE clade of AP2 domain transcription factors activates wax biosynthesis, alters cuticle properties, and confers drought tolerance when overexpressed in Arabidopsis. The Plant Cell. 2004, 16 (9), 2463-2480. 
22. Ashraf, J.; Zuo, D.; Wang, Q.; Malik, W.; Zhang, Y.; Abid, M. A.; Cheng, H.; Yang, Q.; Song, G., Recent insights into cotton functional genomics: progress and future perspectives. Plant biotechnology journal. 2018, 16 (3), 699-713.

23. Zhou, J.; Tang, X.; Martin, G. B., The Pto kinase conferring resistance to tomato bacterial speck disease interacts with proteins that bind a cis-element of pathogenesis-related genes. The EMBO Journal. 1997, 16 (11), 3207-3218.

24. Jin, L. G.; Li, H.; Liu, J. Y., Molecular characterization of three ethylene responsive element binding factor genes from cotton. Journal of integrative plant biology. 2010, 52 (5), 485-495.

25. Sharma, M. K.; Kumar, R.; Solanke, A. U.; Sharma, R.; Tyagi, A. K.; Sharma, A. K., Identification, phylogeny, and transcript profiling of ERF family genes during development and abiotic stress treatments in tomato. Molecular Genetics and Genomics. 2010, 284 (6), 455475 .

26. Okamuro, J. K.; Caster, B.; Villarroel, R.; Van Montagu, M.; Jofuku, K. D., The AP2 domain of APETALA2 defines a large new family of DNA binding proteins in Arabidopsis. Proceedings of the National Academy of Sciences. 1997, 94 (13), 7076-7081.

27. Weigel, D., The APETALA2 domain is related to a novel type of DNA binding domain. The Plant Cell. 1995, 7 (4), 388.

28. Licausi, F.; Ohme-Takagi, M.; Perata, P., APETALA 2/Ethylene Responsive Factor (AP 2/ERF) transcription factors: Mediators of stress responses and developmental programs. New Phytologist. 2013, 199 (3), 639-649.

29. Zhuang, J.; Cai, B.; Peng, R.-H.; Zhu, B.; Jin, X.-F.; Xue, Y.; Gao, F.; Fu, X.-Y.; Tian, Y.-S.; Zhao, W., Genome-wide analysis of the AP2/ERF gene family in Populus trichocarpa. Biochemical and biophysical research communications. 2008, 371 (3), 468-474.

30. Jin, L.-G.; Liu, J.-Y., Molecular cloning, expression profile and promoter analysis of a novel ethylene responsive transcription factor gene GhERF4 from cotton (Gossypium hirstum). Plant Physiology and Biochemistry. 2008, 46 (1), 46-53.

31. Zhang, G.; Chen, M.; Chen, X.; Xu, Z.; Guan, S.; Li, L.-C.; Li, A.; Guo, J.; Mao, L.; Ma, Y., Phylogeny, gene structures, and expression patterns of the ERF gene family in soybean (Glycine max L.). Journal of experimental botany. 2008, 59 (15), 4095-4107.

32. Gil-Humanes, J.; Pistón, F.; Martín, A.; Barro, F., Comparative genomic analysis and expression of the APETALA2-like genes from barley, wheat, and barley-wheat amphiploids. BMC plant biology. 2009, 9 (1), 66. 
33. Zhuang, J.; Deng, D.-X.; Yao, Q.-H.; Zhang, J.; Xiong, F.; Chen, J.-M.; Xiong, A.-S., Discovery, phylogeny and expression patterns of AP2-like genes in maize. Plant Growth Regulation. 2010, 62 (1), 51-58.

34. Hu, L.; Liu, S., Genome-wide identification and phylogenetic analysis of the ERF gene family in cucumbers. Genetics and Molecular Biology. 2011, 34 (4), 624-634.

35. Zhuang, J.; Chen, J.-M.; Yao, Q.-H.; Xiong, F.; Sun, C.-C.; Zhou, X.-R.; Zhang, J.; Xiong, A.-S., Discovery and expression profile analysis of AP2/ERF family genes from Triticum aestivum. Molecular biology reports. 2011, 38 (2), 745-753.

36. Rashid, M.; Guangyuan, H.; Guangxiao, Y.; Hussain, J.; Xu, Y., AP2/ERF transcription factor in rice: genome-wide canvas and syntenic relationships between monocots and eudicots. Evolutionary Bioinformatics. 2012, 8, EBO. S9369.

37. Yan, H.; Hong, L.; Zhou, Y.; Jiang, H.; Zhu, S.; Fan, J.; Cheng, B., A genome-wide analysis of the ERF gene family in sorghum. Genet Mol Res. 2013, 12 (2), 2038-2055.

38. Zhang, H.; Zhang, J.; Quan, R.; Pan, X.; Wan, L.; Huang, R., EAR motif mutation of rice OsERF3 alters the regulation of ethylene biosynthesis and drought tolerance. Planta. 2013, 237 (6), 1443-1451.

39. Charfeddine, M.; Saïdi, M. N.; Charfeddine, S.; Hammami, A.; Bouzid, R. G., Genomewide analysis and expression profiling of the ERF transcription factor family in potato (Solanum tuberosum L.). Molecular biotechnology. 2015, 57 (4), 348-358.

40. Zarei, A.; Körbes, A. P.; Younessi, P.; Montiel, G.; Champion, A.; Memelink, J., Two GCC boxes and AP2/ERF-domain transcription factor ORA59 in jasmonate/ethylene-mediated activation of the PDF1. 2 promoter in Arabidopsis. Plant molecular biology. 2011, 75 (4-5), $321-331$.

41. Lee, J.-H.; Hong, J.-P.; Oh, S.-K.; Lee, S.; Choi, D.; Kim, W., The ethylene-responsive factor like protein 1 (CaERFLP1) of hot pepper (Capsicum annuum L.) interacts in vitro with both GCC and DRE/CRT sequences with different binding affinities: possible biological roles of CaERFLP1 in response to pathogen infection and high salinity conditions in transgenic tobacco plants. Plant molecular biology. 2004, 55 (1), 61-81.

42. Shoji, T.; Mishima, M.; Hashimoto, T., Divergent DNA-binding specificities of a group of ETHYLENE RESPONSE FACTOR transcription factors involved in plant defense. Plant physiology. 2013, 162 (2), 977-990. 
43. Hao, D.; Ohme-Takagi, M.; Sarai, A., Unique mode of GCC box recognition by the DNAbinding domain of ethylene-responsive element-binding factor (ERF domain) in plant. Journal of Biological Chemistry. 1998, 273 (41), 26857-26861.

44. Wan, L.; Wu, Y.; Huang, J.; Dai, X.; Lei, Y.; Yan, L.; Jiang, H.; Zhang, J.; Varshney, R. K.; Liao, B., Identification of ERF genes in peanuts and functional analysis of AhERF008 and AhERF019 in abiotic stress response. Functional \& integrative genomics. 2014, 14 (3), 467-477.

45. Hiratsu, K.; Matsui, K.; Koyama, T.; Ohme-Takagi, M., Dominant repression of target genes by chimeric repressors that include the EAR motif, a repression domain, in Arabidopsis. The Plant Journal. 2003, 34 (5), 733-739.

46. Ikeda, M.; Ohme-Takagi, M., A novel group of transcriptional repressors in Arabidopsis. Plant and cell physiology. 2009, 50 (5), 970-975.

47. Mizoi, J.; Ohori, T.; Moriwaki, T.; Kidokoro, S.; Todaka, D.; Maruyama, K.; Kusakabe, K.; Osakabe, Y.; Shinozaki, K.; Yamaguchi-Shinozaki, K., GmDREB2A; 2, a canonical DEHYDRATION-RESPONSIVE ELEMENT-BINDING PROTEIN2-type transcription factor in soybean, is posttranslationally regulated and mediates dehydration-responsive element-dependent gene expression. Plant physiology. 2013, 161 (1), 346-361.

48. Yang, Z.; Tian, L.; Latoszek-Green, M.; Brown, D.; Wu, K., Arabidopsis ERF4 is a transcriptional repressor capable of modulating ethylene and abscisic acid responses. Plant molecular biology. 2005, 58 (4), 585-596.

49. Zhang, H.; Li, W.; Chen, J.; Yang, Y.; Zhang, Z.; Zhang, H.; Wang, X.-C.; Huang, R., Transcriptional activator TSRF1 reversely regulates pathogen resistance and osmotic stress tolerance in tobacco. Plant molecular biology. 2007, 63 (1), 63-71.

50. Pandey, G. K.; Grant, J. J.; Cheong, Y. H.; Kim, B. G.; Li, L.; Luan, S., ABR1, an APETALA2-domain transcription factor that functions as a repressor of ABA response in Arabidopsis. Plant Physiology. 2005, 139 (3), 1185-1193.

51. Lee, S.-j.; Park, J. H.; Lee, M. H.; Yu, J.-h.; Kim, S. Y., Isolation and functional characterization of CE1 binding proteins. BMC plant biology. 2010, 10 (1), 277.

52. Lee, S.-b.; Lee, S.-j.; Kim, S. Y., AtERF15 is a positive regulator of ABA response. Plant cell reports 2015, 34 (1), 71-81.

53. Lee, J.-H.; Kim, D.-M.; Lee, J. H.; Kim, J.; Bang, J. W.; Kim, W. T.; Pai, H.-S., Functional characterization of NtCEF1, an AP2/EREBP-type transcriptional activator highly expressed in tobacco callus. Planta. 2005, 222 (2), 211-224. 
54. Zhang, Z.; Wang, J.; Zhang, R.; Huang, R., The ethylene response factor AtERF98 enhances tolerance to salt through the transcriptional activation of ascorbic acid synthesis in Arabidopsis. The Plant Journal. 2012, 71 (2), 273-287.

55. Oñate-Sánchez, L.; Anderson, J. P.; Young, J.; Singh, K. B., AtERF14, a member of the ERF family of transcription factors, plays a nonredundant role in plant defense. Plant Physiology. 2007, 143 (1), 400-409.

56. Catinot, J.; Huang, J. B.; Huang, P. Y.; Tseng, M. Y.; Chen, Y. L.; Gu, S. Y.; Lo, W. S.; Wang, L. C.; Chen, Y. R.; Zimmerli, L., ETHYLENE RESPONSE FACTOR 96 positively regulates A rabidopsis resistance to necrotrophic pathogens by direct binding to GCC elements of jasmonate-and ethylene-responsive defence genes. Plant, cell \& environment. 2015, 38 (12), 2721-2734.

57. Müller, M.; Munné-Bosch, S., Ethylene response factors: a key regulatory hub in hormone and stress signaling. Plant physiology. 2015, 169 (1), 32-41.

58. Park, J. M.; Park, C.-J.; Lee, S.-B.; Ham, B.-K.; Shin, R.; Paek, K.-H., Overexpression of the tobacco Tsil gene encoding an EREBP/AP2-type transcription factor enhances resistance against pathogen attack and osmotic stress in tobacco. The Plant Cell. 2001, 13 (5), 1035-1046.

59. Huang, G.-T.; Ma, S.-L.; Bai, L.-P.; Zhang, L.; Ma, H.; Jia, P.; Liu, J.; Zhong, M.; Guo, Z.-F., Signal transduction during cold, salt, and drought stresses in plants. Molecular biology reports. 2012, 39 (2), 969-987.

60. Sharma, R.; De Vleesschauwer, D.; Sharma, M. K.; Ronald, P. C., Recent advances in dissecting stress-regulatory crosstalk in rice. Molecular Plant. 2013, 6 (2), 250-260.

61. Zhu, J.-K., Cell signaling under salt, water and cold stresses. Current opinion in plant biology. 2001, 4 (5), 401-406.

62. Kang, Y.; Khan, S.; Ma, X., Climate change impacts on crop yield, crop water productivity and food security-A review. Progress in natural Science. 2009, 19 (12), 1665-1674.

63. Kasuga, M.; Liu, Q.; Miura, S.; Yamaguchi-Shinozaki, K.; Shinozaki, K., Improving plant drought, salt, and freezing tolerance by gene transfer of a single stress-inducible transcription factor. Nature biotechnolog.y 1999, 17 (3), 287-291.

64. Maruyama, K.; Takeda, M.; Kidokoro, S.; Yamada, K.; Sakuma, Y.; Urano, K.; Fujita, M.; Yoshiwara, K.; Matsukura, S.; Morishita, Y., Metabolic pathways involved in cold acclimation identified by integrated analysis of metabolites and transcripts regulated by DREB1A and DREB2A. Plant physiology. 2009, 150 (4), 1972-1980. 
65. Alonso-Blanco, C.; Gomez-Mena, C.; Llorente, F.; Koornneef, M.; Salinas, J.; MartínezZapater, J. M., Genetic and molecular analyses of natural variation indicate CBF2 as a candidate gene for underlying a freezing tolerance quantitative trait locus in Arabidopsis. Plant Physiology. 2005, 139 (3), 1304-1312.

66. Sharabi-Schwager, M.; Lers, A.; Samach, A.; Guy, C. L.; Porat, R., Overexpression of the CBF2 transcriptional activator in Arabidopsis delays leaf senescence and extends plant longevity. Journal of experimental botany. 2010, 61 (1), 261-273.

67. Sakuma, Y.; Maruyama, K.; Osakabe, Y.; Qin, F.; Seki, M.; Shinozaki, K.; YamaguchiShinozaki, K., Functional analysis of an Arabidopsis transcription factor, DREB2A, involved in drought-responsive gene expression. The Plant Cell. 2006, 18 (5), 1292-1309.

68. Sakuma, Y.; Maruyama, K.; Qin, F.; Osakabe, Y.; Shinozaki, K.; Yamaguchi-Shinozaki, K., Dual function of an Arabidopsis transcription factor DREB2A in water-stress-responsive and heat-stress-responsive gene expression. Proceedings of the National Academy of Sciences. 2006, 103 (49), 18822-18827.

69. Hinz, M.; Wilson, I. W.; Yang, J.; Buerstenbinder, K.; Llewellyn, D.; Dennis, E. S.; Sauter, M.; Dolferus, R., Arabidopsis RAP2. 2: an ethylene response transcription factor that is important for hypoxia survival. Plant physiology. 2010, 153 (2), 757-772.

70. Gibbs, D. J.; Lee, S. C.; Isa, N. M.; Gramuglia, S.; Fukao, T.; Bassel, G. W.; Correia, C. S.; Corbineau, F.; Theodoulou, F. L.; Bailey-Serres, J., Homeostatic response to hypoxia is regulated by the $\mathrm{N}$-end rule pathway in plants. Nature. 2011, 479 (7373), 415-418.

71. Licausi, F.; Kosmacz, M.; Weits, D. A.; Giuntoli, B.; Giorgi, F. M.; Voesenek, L. A.; Perata, P.; van Dongen, J. T., Oxygen sensing in plants is mediated by an N-end rule pathway for protein destabilization. Nature. 2011, 479 (7373), 419-422.

72. Licausi, F.; Van Dongen, J. T.; Giuntoli, B.; Novi, G.; Santaniello, A.; Geigenberger, P.; Perata, P., HRE1 and HRE2, two hypoxia-inducible ethylene response factors, affect anaerobic responses in Arabidopsis thaliana. The Plant Journal. 2010, 62 (2), 302-315.

73. Hattori, Y.; Nagai, K.; Furukawa, S.; Song, X.-J.; Kawano, R.; Sakakibara, H.; Wu, J.; Matsumoto, T.; Yoshimura, A.; Kitano, H., The ethylene response factors SNORKEL1 and SNORKEL2 allow rice to adapt to deep water. Nature. 2009, 460 (7258), 1026-1030.

74. Xu, K.; Xu, X.; Fukao, T.; Canlas, P.; Maghirang-Rodriguez, R.; Heuer, S.; Ismail, A. M.; Bailey-Serres, J.; Ronald, P. C.; Mackill, D. J., Sub1A is an ethylene-response-factor-like gene that confers submergence tolerance to rice. Nature. 2006, 442 (7103), 705-708. 
75. Mito, T.; Seki, M.; Shinozaki, K.; Ohme-Takagi, M.; Matsui, K., Generation of chimeric repressors that confer salt tolerance in Arabidopsis and rice. Plant Biotechnology Journal. 2011, 9 (7), 736-746.

76. Moffat, C. S.; Ingle, R. A.; Wathugala, D. L.; Saunders, N. J.; Knight, H.; Knight, M. R., ERF5 and ERF6 play redundant roles as positive regulators of JA/Et-mediated defense against Botrytis cinerea in Arabidopsis. PloS one. 2012, 7 (4).

77. Li, Z.; Zhang, L.; Yu, Y.; Quan, R.; Zhang, Z.; Zhang, H.; Huang, R., The ethylene response factor AtERF11 that is transcriptionally modulated by the bZIP transcription factor HY5 is a crucial repressor for ethylene biosynthesis in Arabidopsis. The Plant Journal. 2011, $68(1), 88-99$.

78. Chen, X.; Guo, Z., Tobacco OPBP1 enhances salt tolerance and disease resistance of transgenic rice. International journal of molecular sciences. 2008, 9 (12), 2601-2613.

79. Rong, W.; Qi, L.; Wang, A.; Ye, X.; Du, L.; Liang, H.; Xin, Z.; Zhang, Z., The ERF transcription factor Ta ERF 3 promotes tolerance to salt and drought stresses in wheat. Plant biotechnology journal. 2014, 12 (4), 468-479.

80. Scarpeci, T. E.; Frea, V. S.; Zanor, M. I.; Valle, E. M., Overexpression of AtERF019 delays plant growth and senescence, and improves drought tolerance in Arabidopsis. Journal of experimental botany. 2017, 68 (3), 673-685.

81. Pellegrineschi, A.; Reynolds, M.; Pacheco, M.; Brito, R. M.; Almeraya, R.; YamaguchiShinozaki, K.; Hoisington, D., Stress-induced expression in wheat of the Arabidopsis thaliana DREB1A gene delays water stress symptoms under greenhouse conditions. Genome. 2004, 47 (3), 493-500.

82. Trujillo, L. E.; Menéndez, C.; Ochogavía, M. E.; Hernández, I.; Borrás, O.; Rodríguez, R.; Coll, Y.; Arrieta, J. G.; Banguela, A.; Ramírez, R., Engineering drought and salt tolerance in plants using SodERF3, a novel sugarcane ethylene responsive factor. Biotecnología Aplicada. 2009, 26 (2), 168-171.

83. Joo, J.; Choi, H. J.; Lee, Y. H.; Kim, Y.-K.; Song, S. I., A transcriptional repressor of the ERF family confers drought tolerance to rice and regulates genes preferentially located on chromosome 11. Planta. 2013, 238 (1), 155-170.

84. Song, C.-P.; Agarwal, M.; Ohta, M.; Guo, Y.; Halfter, U.; Wang, P.; Zhu, J.-K., Role of an Arabidopsis AP2/EREBP-type transcriptional repressor in abscisic acid and drought stress responses. The Plant Cell. 2005, 17 (8), 2384-2396. 
85. Zhai, Y.; Li, J.-W.; Li, X.-W.; Lei, T.-T.; Yan, F.; Zhao, Y.; Li, Y.-J.; Su, L.-T.; Wang, Y.; Wang, Q.-Y., Isolation and characterization of a novel transcriptional repressor GmERF6 from soybean. Biologia plantarum. 2013, 57 (1), 26-32.

86. Upadhyay, R. K.; Gupta, A.; Ranjan, S.; Singh, R.; Pathre, U. V.; Nath, P.; Sane, A. P., The EAR motif controls the early flowering and senescence phenotype mediated by overexpression of SIERF36 and is partly responsible for changes in stomatal density and photosynthesis. PloS one. 2014, 9 (7).

87. Bi, H.; Yang, B., Gene editing with TALEN and CRISPR/Cas in rice. In Progress in molecular biology and translational science, Elsevier: 2017; Vol. 149, pp 81-98.

88. Li, J.; Meng, X.; Zong, Y.; Chen, K.; Zhang, H.; Liu, J.; Li, J.; Gao, C., Gene replacements and insertions in rice by intron targeting using CRISPR-Cas9. Nature plants. 2016, 2 (10), 1-6.

89. Hoang, T. M. L.; Tran, T. N.; Nguyen, T. K. T.; Williams, B.; Wurm, P.; Bellairs, S.; Mundree, S., Improvement of salinity stress tolerance in rice: challenges and opportunities. Agronomy. 2016, 6 (4), 54.

90. Shen, C.; Que, Z.; Xia, Y.; Tang, N.; Li, D.; He, R.; Cao, M., Knock out of the annexin gene OsAnn3 via CRISPR/Cas9-mediated genome editing decreased cold tolerance in rice. Journal of Plant Biology. 2017, 60 (6), 539-547.

91. Mao, Y.; Zhang, Z.; Feng, Z.; Wei, P.; Zhang, H.; Botella, J. R.; Zhu, J. K., Development of germ-line-specific CRISPR-Cas9 systems to improve the production of heritable gene modifications in Arabidopsis. Plant biotechnology journal. 2016, 14 (2), 519-532.

92. Fan, W.; Hai, M.; Guo, Y.; Ding, Z.; Tie, W.; Ding, X.; Yan, Y.; Wei, Y.; Liu, Y.; $\mathrm{Wu}, \mathrm{C}$., The ERF transcription factor family in cassava: genome-wide characterization and expression analyses against drought stress. Scientific reports. 2016, 6, 37379.

93. Liu, J.; Wang, F.; Yu, G.; Zhang, X.; Jia, C.; Qin, J.; Pan, H., Functional analysis of the maize C-repeat/DRE motif-binding transcription factor $\mathrm{CBF} 3$ promoter in response to abiotic stress. International journal of molecular sciences. 2015, 16 (6), 12131-12146.

94. Wang, Z.; Zhang, N.; Zhou, X.; Fan, Q.; Si, H.; Wang, D., Isolation and characterization of StERF transcription factor genes from potato (Solanum tuberosum L.). Comptes rendus biologies 2015, 338 (4), 219-226.

95. Klay, I.; Pirrello, J.; Riahi, L.; Bernadac, A.; Cherif, A.; Bouzayen, M.; Bouzid, S., Ethylene response factor Sl-ERF. B. 3 is responsive to abiotic stresses and mediates salt and cold stress response regulation in tomato. The Scientific World Journal. 2014, 2014. 
96. Li, R.; Zhang, L.; Wang, L.; Chen, L.; Zhao, R.; Sheng, J.; Shen, L., Reduction of tomato-plant chilling tolerance by CRISPR-Cas9-mediated SICBF1 mutagenesis. Journal of agricultural and food chemistry. 2018, 66 (34), 9042-9051. 